\title{
Geomorfološka obilježja gornjeg toka rijeke Sutle
}

\author{
Zdravka Žiger, Andrija Bognar
}

\begin{abstract}
Dolina rijeke Sutle oblikovana je na području SZ Hrvatske u sklopu Panonskog bazena. Geomorfološkom analizom i sintezom te metodom geomorfološkog kartiranja istražena je dolina gornjeg toka rijeke Sutle od izvora do Kumrovečke zavale. Kompozitno obilježje doline je reljefni izraz njenog složenog geomorfološkog razvoja. U njenom oblikovanju odlučujući su utjecaj imali fluvio - denudacijski, fluvijalni procesi i tektonika.

Ključne riječi: geomorfološka analiza, geomorfološko kartiranje, fluvijalni procesi, tektonika, Sutla
\end{abstract}

\section{Geomorphological Characteristic of Upper Flow River Sutla}

River Sutla valley was developed as a part of Panonian basin in NW part of Croatia. The research of upper flow river Sutla from well till plain of Kumrovec has been made using analysis, synthesis and the methods of geomorphological mapping. Character of valley is complex. Valley is poligenetic origin, which means that in it's modeling fluvial and denudation processes and tectonic had the major influence.

Keywords: geomorphologic analysis, geomorphologic mapping, fluvial processes, tectonics, Sutla

\section{UVOD}

Dolina rijeke Sutle dio je makrogeomorfološke regije gorsko-zavalskog prostora SZ Hrvatske i SI Slovenije. Gornji tok rijeke između njenog izvorišnog dijela u pobrđu Maceljske gore pa do Zagorskih Sela dio je mezogeomorfološke cjeline gorskih nizova i pobrđe Hrvatskog zagorja, koja je pak u širem smislu dio megageomorfološke regije Panonskog bazena. (Bognar 1999.)

Područje istraživanja ovog rada, od izvora do Kumrovečke zavale, dosad je proučavano kao dio većih cjelina. Geotektonski kontakt Panonskog bazena, Unutrašnjih Dinarida, te istočnih Alpa u okviru istraživanog područja u znatnoj je mjeri utjecao na relativno složen geomorfološki razvoj doline rijeke Sutle i njenog bazena poriječja. Reljefni izraz toga jest kompozitni karakter doline. To znači da se na uzdužnom profilu doline smjenjuju kotlinska proširenja i suženja-sutjeske. To je obilježje doline rijeke Sutle od izvora do Zagorskih Sela: uski duboki izvorišni dio doline $\mathrm{V}$ izreza poprečnog profila, dolinsko proširenje kod Lupinjaka - Hromca, zatim slijedi sutjeska - suženje Sutle nizvodno od Strmca Humskog do Rogateca, relativno uska dolina ravnog dna (dijelom ujezerena - Sutlansko jezero) 
između Atomskih toplica i Rogateca, suženje - sutjeska s obilježjem probojnice između Desinićke gore (Štruklečev brijeg, 485 m) i gorskog uzvišenja Rudnice (Plešivec, 686 m) te konačno proširenje doline između Poljane Sutlanske i Zagorskih Sela.

Navedeni dijelovi doline ulaze u okvire više subgeomorfoloških regionalnih cjelina:

1. Dolinsko proširenje između Zagorskih Sela i Miljane, te sutjeska između Desinićke gore i Rudnice participiraju u submorfološkoj regiji Kuna-gore i Desinićke gore s predgorskim stepenicama, pobrđem Horvatske te Marijagoričkim pobrđem. U tu submorfološku regiju prirodno ulaze i gorsko uzvišenje Rudnice, te pobrđe sa slovenske (zapadne) doline Sutle između Miljane i Zagorskih Sela. ${ }^{1}$

2. Uzvodni dio rijeke Sutle sve do njenog izvorišta, svojim najvećim dijelom ulazi u subgeomorfološku cjelinu Ravne gore s Maceljskim pobrđem. Izuzetak čini samo ujezereni dio doline u SZ podnožju Desiničke gore koji se može shvatiti kao dio prve spomenute submorfološke regije (Sl. 1).

Unutar navedenih subgeomorfoloških regija izdvojiti se može nekoliko mikrogeomorfoloških regionalnih cjelina: istočni dio pobrđa Horvatske, dolina rijeke Sutle između Miljane i Zagorskih sela, zapadni dio pobrđa Horvatske (u Republici Sloveniji), gorski hrbat Desinićke gore i gorski hrbat Rudnice (u Republici Sloveniji) mikroregije su subgeomorfološke cjeline Kuna-i Desinić- gore i gorskog hrpta Rudnice s predgorskim stepenicama i pobrđem Horvatske, dok je podgorje Vinagore i Kuna-gore s dolinom Sutle s Maceljskim gorjem mikroregija subgeomorfološke regije Ravne gore s Maceljskim pobrđem.

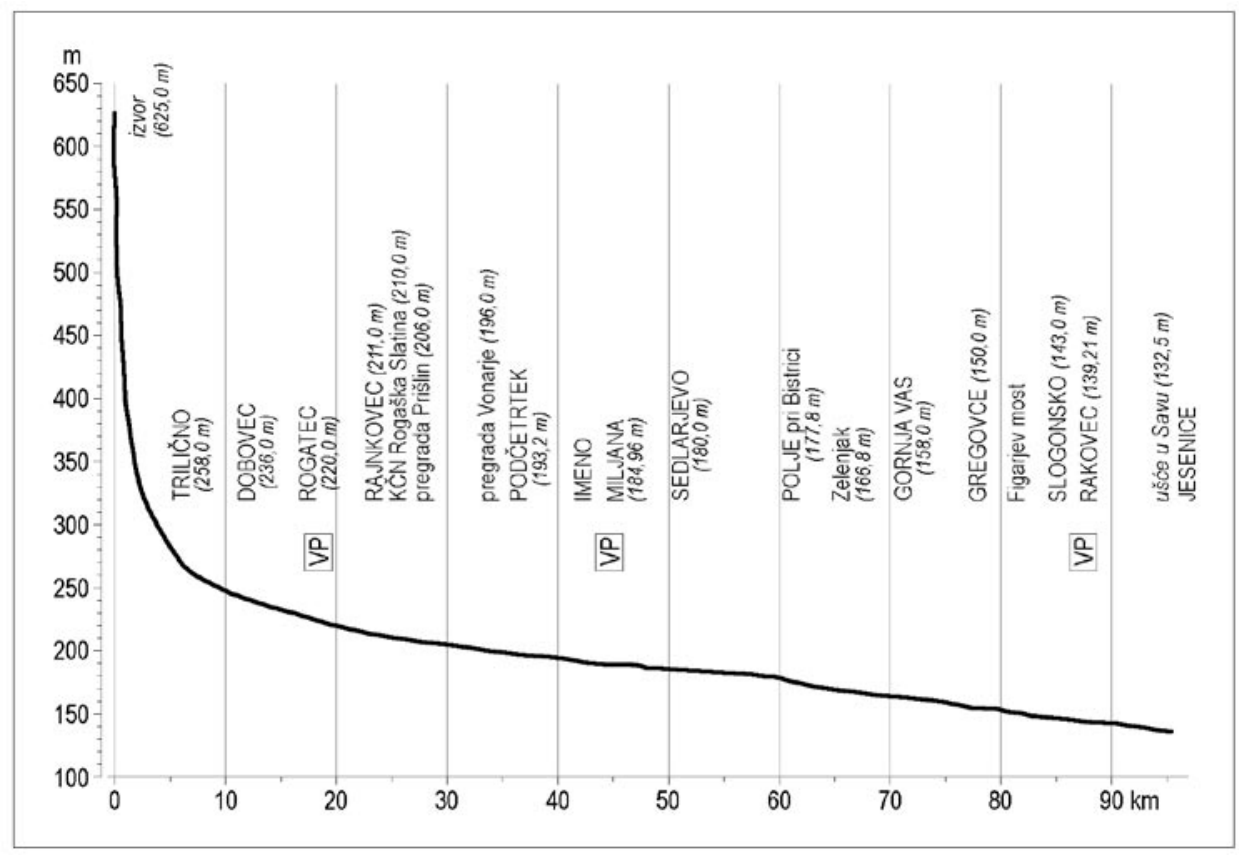

S1.1. Uzdužni profil rijeke Sutle sa «0» kotama

Fig.1. Longitudinal profile of the river Sutla with «0» point elevations of water level. 
Za nastanak doline važna je geotektonska evolucija područja najmlađe neotektonske faze tijekom pliocena i kvartara kada je došlo do izmjene tektonskog potiska iz pravca JZ-SI u pravac SSZ-JJI. U bazenu poriječja prevladavaju neogenske i kvartarne naslage. Izuzetak tome čine dijelovi područja gorskog hrpta Desinićke gore i gorskog hrpta Rudnice oblikovane u dolomitima trijaske starosti.

\section{GEOMORFOLOŠKA ANALIZA}

Dolina rijeke Sutle oblikovana je međuovisnošću djelovanja fluvijalnih i derazijskih procesa i tektonskih pokreta, posebno onih tijekom mlađe neotektonske faze geotektonske evolucije područja. U skladu s tim različitim prirodno-geografskim i geološkim preduvjetima u pojedinim fazama modeliranja doline Sutle, ona ne pokazuje jedinstvena geomorfološka obilježja. U orografskom i morfogenetskom, te morfostrukturnom smislu može se izdvojiti šest jasno diferenciranih dijelova doline Sutle, i to:

1. Izvorišni dio doline Sutle u okviru Maceljskog pobrđa (od izvora do Hromca)

2. Dolinsko proširenje Sutle od Hromca do Strmca Humskog

3. Sutjeska Sulte od Strmca Humskog do početka proširenja doline Sutle, istočno od Rogateca

4. Relativno uska dolina Sutle ravnog dna od Rogateca do Atomskih toplica (djelomično ujezerena-Sutlansko jezero) obilježena izmjenom manjih proširenja i suženja

5. Suženje - sutjeska s obilježjem probojnice između Desinić gore i gorskog uzvišenja Rudnice (od Atomskih toplica do poljane Sutlanske)

6. Proširenje doline od Poljane Sutlanske do Zagorskih sela obilježeno s dva manja kotlinska proširenja, prvo u području Miljana - Imeno, a drugo između Zagorskih sela - Sedlarjeva, te manjim suženjem između Plavića - Prelaskog.

Izvorišni dio doline Sutle (od izvora do Hromca) u okviru Maceljskog pobrđa ima obilježja uske duboke doline V izreza poprečnog profila koji nesumnjivo ukazuje na kontinuirano izdizanje. Tektonska predispozicija izražena je u asimetriji dolinskih strana. Pretežito radijalni raspored dolina pritoka i derazijskih dolina pojedinih brdskih uzvišenja uz dolinu dokaz je blokovske mikrotektonske razlomljenosti terena (brdski blok Sp. Log - 486 m, M. Kravnjak, Trubeljak, Jurjevec). U skladu s tim je i energija reljefa koja ulazi u kategoriju raščlanjenog reljefa od 100-300 m/ $\mathrm{km}^{2}$. Nagibi dolinskih strana kreću se od $12-32^{\circ}$.

Dolinsko proširenje Sutle od Hromca do Strmca Humskog također je tektonski preduvjetovano i to križanjem rasjeda pravca pružanja ISI-ZJZ i sa sustavom rasjeda pravca pružanja I-Z. Erozijskom aktivnošću vodotoka intenzivno smrvljenim pretežito klastičnim naslagama oligomiocenske starosti (Ančić, Juriša 1984) dolina je proširena i oblikovana je aluvijalna ravnica. Izražena je relativno velika energija reljefa (preko $100 \mathrm{~m} / \mathrm{km}^{2}$ ) tog dijela bazena poriječja. Razmrvljenost klastičnih naslaga pospješila je aktivnost padinskih procesa što je imalo za posljedicu smanjenje nagiba dolinskih strana $\left(5-12^{\circ}\right)$. I na SZ i na JI dolinskoj strani uočena je pojava erozijskog poda 20 do $50 \mathrm{~m}$ iznad naplavne ravnice 


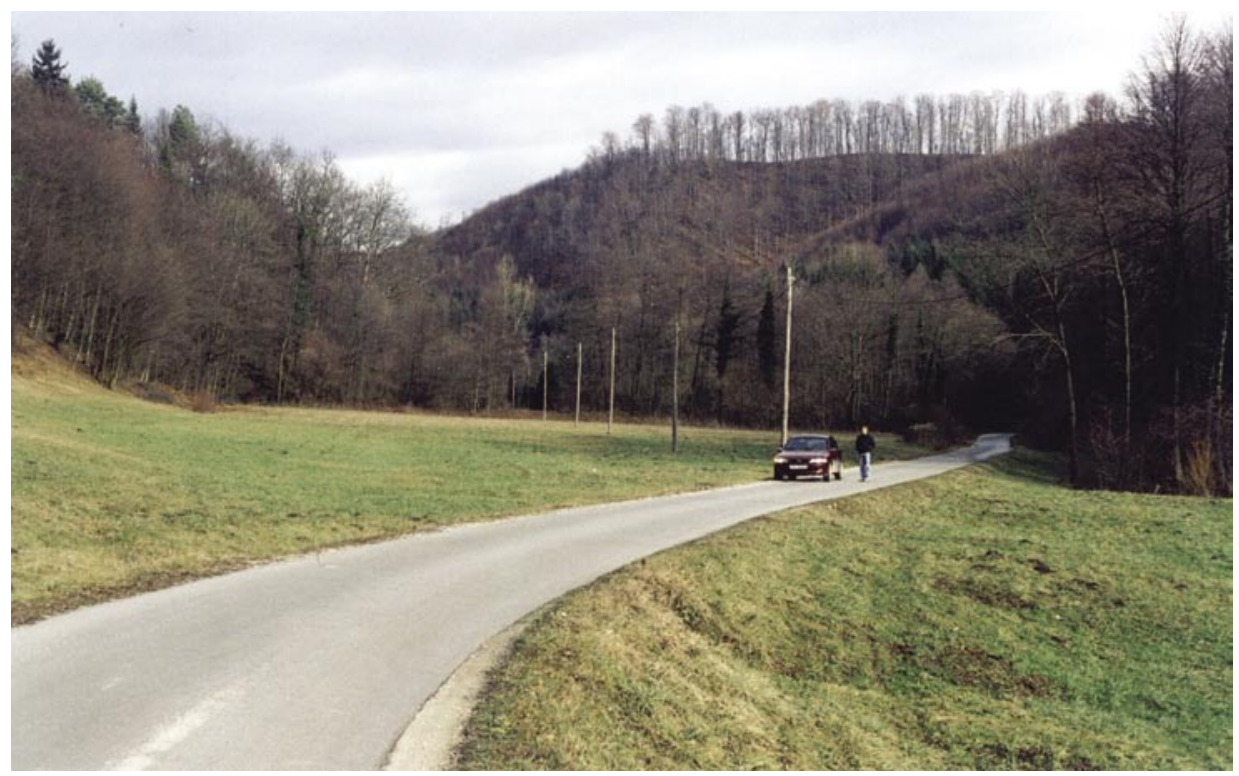

Fot. 1. Pogled prema S na dolinu rijeke Sutle u njenom izvorišnom dijelu prema St. Glažutu, (autor: Andrija Bognar)

Phot. 1. A view (towards the N) of the upper stream of the river Sutla valley near St. Glažut, (author: Andrija Bognar)

toka. Različita visina i diskontinuiranost erozijskog poda s jedne strane je rezultat disekcije poda padinskim procesima spiranja i jaruženja, a s druge različitog intenziteta tektonskih pomaka nakon njihovog oblikovanja (Fot. 1 i 2 ).

Sutjeska Sutle od Strmca Humskog do početka nešto proširenije doline Sutle istočno od Rogateca ima izrazito meandarski ocrt. Oblikovana je na kontaktu miocenskih i oligocenskih klastičnih sedimenata (pješčenjak, kremeni pijesak, konglomerat, pjeskovita glina, pješčani lapor) (Anić, Jutriša 1984). Meandarski ocrt doline je izraz mlađeg intenzivnijeg rasjedno uvjetovanog izdizanja brdskog bloka Strmca Humskog $(381 \mathrm{~m}) \mathrm{i}$ bloka Kurji vrh (354 m). Rijeka Sutla nije mogla svojom erozijskom snagom kompenzirati izdizanje pa je stoga prisiljena zaobići navedene blokove što se odrazilo na vijugavi ocrt njenog uzdužnog profila. Tektonska aktivnost je pojačala i erozijsku snagu vodotoka koji je oblikovao duboku sutjesku strmih strana $\left(12-32^{\circ}\right)$. Izraženija tektonska razlomljenost stijenske podloge rezultirala je intenzivnijom aktivnošću padinskih procesa (jaruženja, spiranje i kliženje). Oblikovan je i niz jaruga i derazijskih dolina.

Relativno uska dolina Sutle ravnog dna od Rogateca do Atomskih toplica obilježena je izmjenom manjih proširenja i suženja. Sutla ima izrazito laktasti ocrt uzdužnog profila što upućuje na tektonsku predispoziciju u oblikovanju doline i to uz rasjede pravca IJI-ZSZ, S-J i SI-JZ. U relativno širokoj rasjednoj zoni IJI-ZSZ, u sektoru Rogatec, dolina uzvodno od Rogateca je uska ravnog dna (100-250 m), dok je nizvodno od Rogateca oblikovano (u dužini od 2,5 km) manje proširenje (maksimalno $500 \mathrm{~m}$ ) s lijepo razvijenom naplavnom ravnicom. Nagibi dolinskih strana su relativno veliki $\left(5-12^{\circ}\right)$. Većina padina je konveksnog 
ocrta što upućuje na mlađu tektonsku aktivnost i izdizanje. I na ovom dijelu doline Sutle su uočeni erozijski podovi manjih relativnih visina (30-50 m). Na sutoku potoka Draganje s rijekom Sutlom unutar samog naselja Rogatec utvrđena su dva akumulacijska terasna fragmenta na kojima su se razvili dijelovi gradskog naselja. Predstavljaju de facto ostatke pleistocenske plavine potoka Draganje koju je rijeka Sutla bočnom erozijom podsjekla oblikovavši vrlo lijepo izražene erozijske strmce.

Slijedi suženje doline Sutle ispod brdskog bloka Vrtlarev brijeg. Kao izraz kompresije dva nasuprotna tektonska bloka, dolina Sutle i njezina aluvijalna ravnica se tu suzuje na 100-150 m širine. Nizvodno od suženja u dužini od 1,5 km dolina Sutle se ponovo proširuje do maksimalno 700-800 m u blizini Malog Tabora. Nastanak proširenja uvjetovano je križanjem rasjeda pravca pružanja IJI-ZSZ koji su mrvljenjem stijenske mase potencirali lateralnu erozijsku snagu vodotoka, ali i padinske procese. Nizvodno slijedi suženje doline na 100-150 m širine na dužini od 150-200 m kao izraz mlađeg izdizanja i kompresije dvaju manjih nasuprotnih brdskih blokova (Rjavice $302 \mathrm{~m}$ i Prišlina $240 \mathrm{~m}$ ). Nizvodno od te sutjeske rijeka Sutla u dužini od $7 \mathrm{~km}$ ima generalno lučni ocrt s tim da u njenom centralnom dijelu izraženo lokalno laktasto skretanje (D. Brezno - Nimno), što je s jedne strane posljedica križanja rasjeda pravca pružanja SSZ-JJI, ISI-ZJZ, ZSZ-IJI i vjerojatno horizontalnog pomaka uz lijevi smičući rasjed pravcem SSZ-JJI. Tu je formirana akumulacija Sutlansko jezero dužine 7 km koja počinje ustavom južnije od Pristavice. Akumulacija ima lučni ocrt generalnog pružanja SZ-JI. Najširi dio akumulacije nalazi se

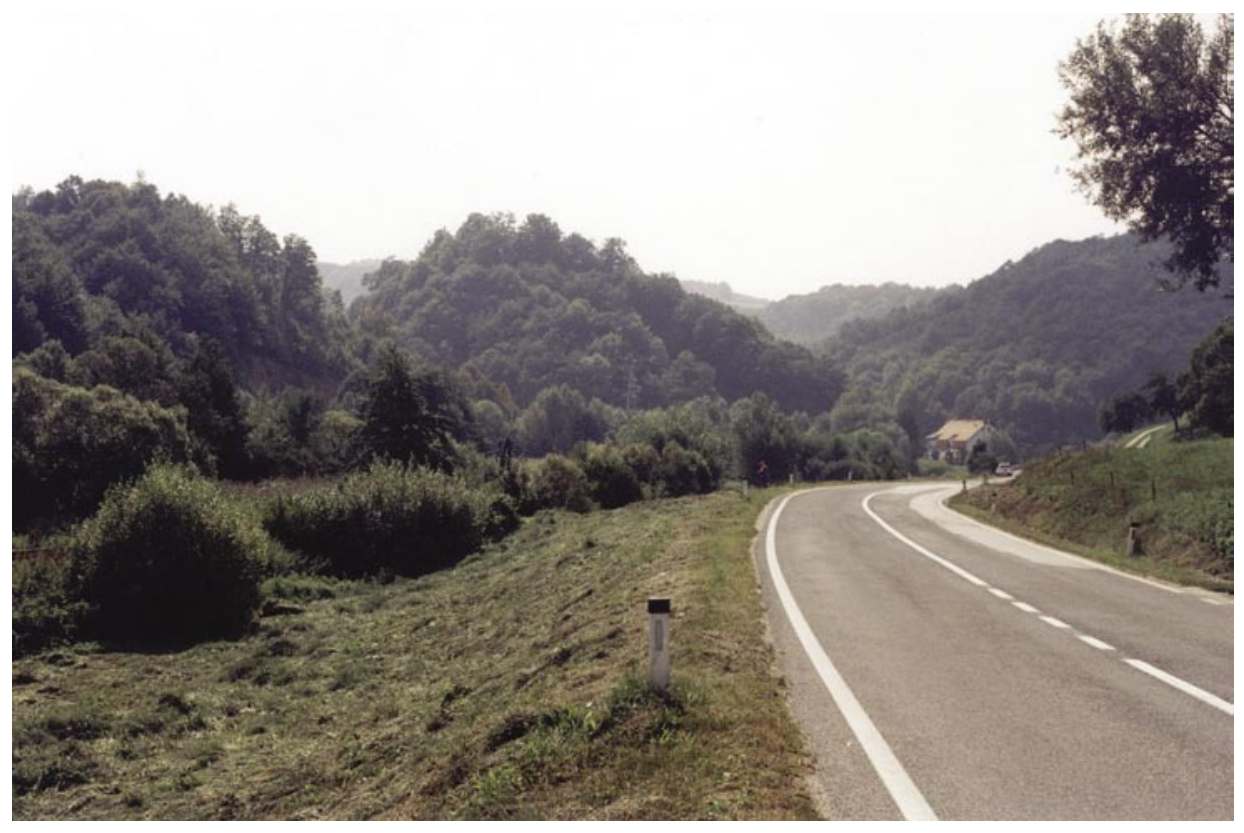

Fot. 2. Pogled prema JI na usku dolinu rijeke Sutle kod Vidina s tragovima erozijskog poda, (autori: Zdravka Žiger Žgela, Andrija Bognar)

Phot. 2. A view (towards the SE) of the narrow part of the river Sutla valley near Vidina showing traces of erosional terraces, (authors: Zdravka Žiger Žgela, Andrija 


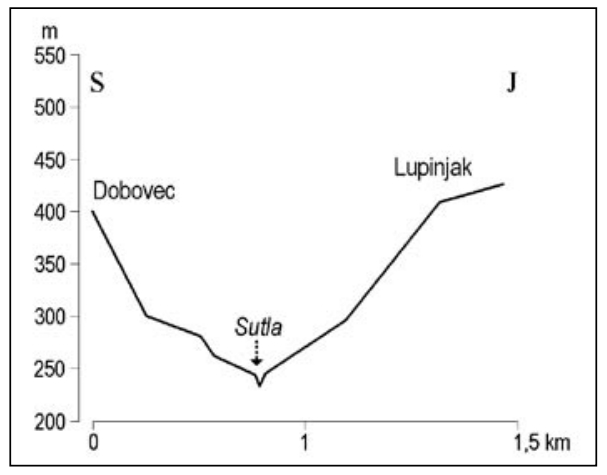

S1. 2. Poprečni morfološki profil doline rijeke Sutle na području Dobovec - Sutla - Lupinjak

Fig. 2. Transversal morphological cross section of the river Sutla valley Dobovec-Sutla-Lupinjak

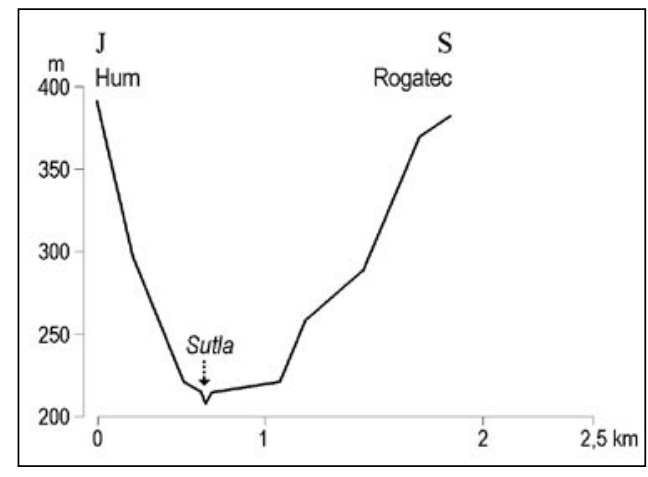

S1. 3. Poprečni morfološki profil doline rijeke Sutle na području Hum na Sutli - Sutla - Rogatec

Fig. 3. Transversal morphological cross section of the river Sutla valley between Hum na Sutli - Sutla-Rogatec

u SZ podnožju gorskog hrpta Desinićke gore (500-700 m). Taj dio doline Sutle predstavlja predgorsku potolinu Desinićke gore koja i danas ima obilježje supsidencije. Na to upućuje širina u suženju doline između SZ padina Desinićke gore na JI i bloka Vonarjeva na SZ. Suženje širine 200-300 m posljedica je kompresije. SZ padina Desinićke gore ima jasno izražen konveksni ocrt što ukazuje na veoma mlado izdizanje područja. Na takav razvoj doline upućuje također i asimetričnost poprečnog profila doline Sutle (Sl. 2, 3 i 4).

Rijeka Sutla od Atomskih toplica do Poljane Sutlanske mijenja pravac svog otjecanja u pravac S-J. Laktasto skrećući, oblikuje sutjesku. Nastanak sutjeske vezan je za izmjene djelovanja tektonskog stresa u neotektonskoj fazi tijekom pliocena i kvartara. Aktiviraju se desna transkurentna kretanja blokova Rudnice i Desinićke gore. To uvjetuje zatvaranje nekadašnjih romboidnih graba ili pull-apart struktura zagorskog tercijarnog bazena i senovske sinklinale (Anić, Jutriša 1984). Navedene pull-apart strukture se zatvaraju, što je u

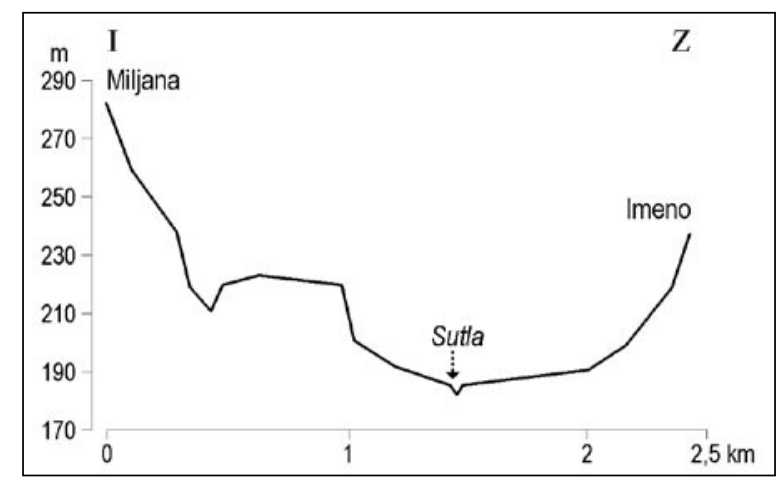

S1. 4. Poprečni morfološki profil doline rijeke Sutle na području Miljana - Sutla - Imeno

Fig.4. Transversal morphological cross section of the river Sutla valley between Miljana - Sutla - Imeno 
reljefu izraženo oblikovanjem derazijsko-erozijskih pobrđa kompresijom miopliocenskih naslaga Velike Horvatske. Ostatak nekadašnje pull-apart strukture je Kumrovečka zavala. U okviru probojnice nagib uzdužnog profila posebno je izražen od Početrtka do Miljane $(165 \mathrm{~cm} / \mathrm{km})$ i predstavlja izraziti pregib rijeke Sutle u odnosu na njen uzvodni i nizvodni dio. Nagibi dolinskih strana su izrazito strmi $\left(12-32^{\circ}\right.$, i više od $\left.32^{\circ}\right)$, posebno $\mathrm{JZ}$ padina Desinićke gore. Energija reljefa je pretežito od $50-100 \mathrm{~cm} / \mathrm{km}^{2}$. Korito rijeke se zbog recentnih tektonskih pokreta «pribilo» uz istočnu stranu doline. U uzdužnom profilu same sutjeske uočljiva su manja proširenja i suženja što upućuje na mikrotektonsku razlomljenost i na horizontalne pokrete. Sutjeska Sutle od Atomskih toplica do Poljane Sutlanske ima dvostruki Z ocrt svog uzdužnog profila. To se može objasniti rotirajućim i horizontalnim smičućim pomacima blok struktura Desinićke gore i Rudnice.

Oblikovanje sutjeske rijeke Sutle kod Podčetrtka može se protumačiti na dva načina. Prvo objašnjanje je nastanak sutjeske epigenetskim tipom morfogeneze u okviru koje se jasno izdvajaju dvije etape. Prva pretpostavlja više-manje zaravnjen reljef i pokrivenost blokova Desinićke gore i Rudnice klastičnim naslagama neogenske starosti, da bi se u drugoj etapi rijeka usijecala u dolomitne blokove trijaske starosti. Paralelno s usijecanjem rijeke u temeljnu stijenu, klastični sedimenti su utjecajem padinskih i erozijskih procesa destruirani, što je rezultiralo ekshumiranjem dolomita. Tome je pridonijelo i intenzivno izdizanje blokova Desinićke gore i Rudnice (Bognar, usmeno).

Drugo moguće objašnjenje nastanka sutjeske veže se za izmjenu djelovanja tektonskog stresa i rotiranja geoloških struktura u novijoj fazi neotektonske etape razvoja prostora. Različito orijentirani dijelovi sutjeske Sutle zatvaraju relativno oštre kutove oblikujući

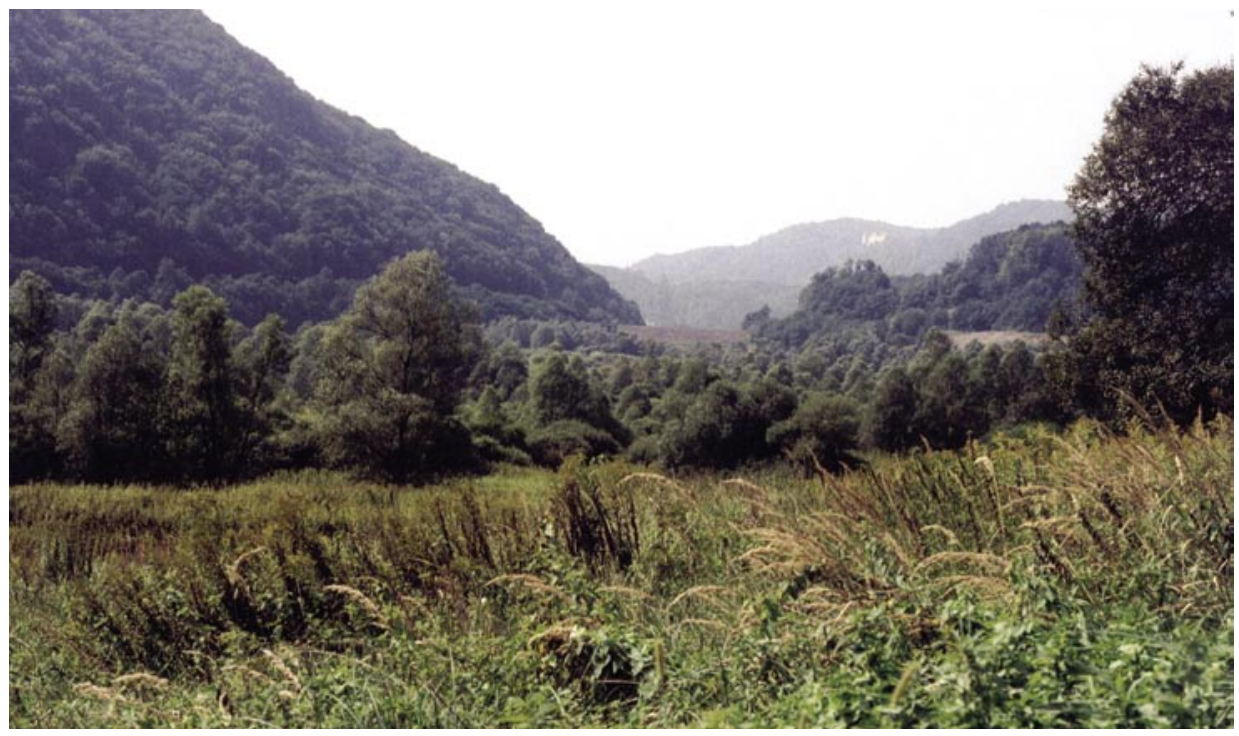

Fot. 3. Pogled prema IJI na probojnicu rijeke Sutle između Rudnice i Desinićke gore i stari grad Podčetrtek, (autori: Zdravka Žiger Žgela, Andrija Bognar)

Phot. 3. A view (towards the ESE) of the river Sutla canyon between the ranges of Rudnica and Desinićka gora, (authors: Zdravka Žiger Žgela, Andrija Bognar) 


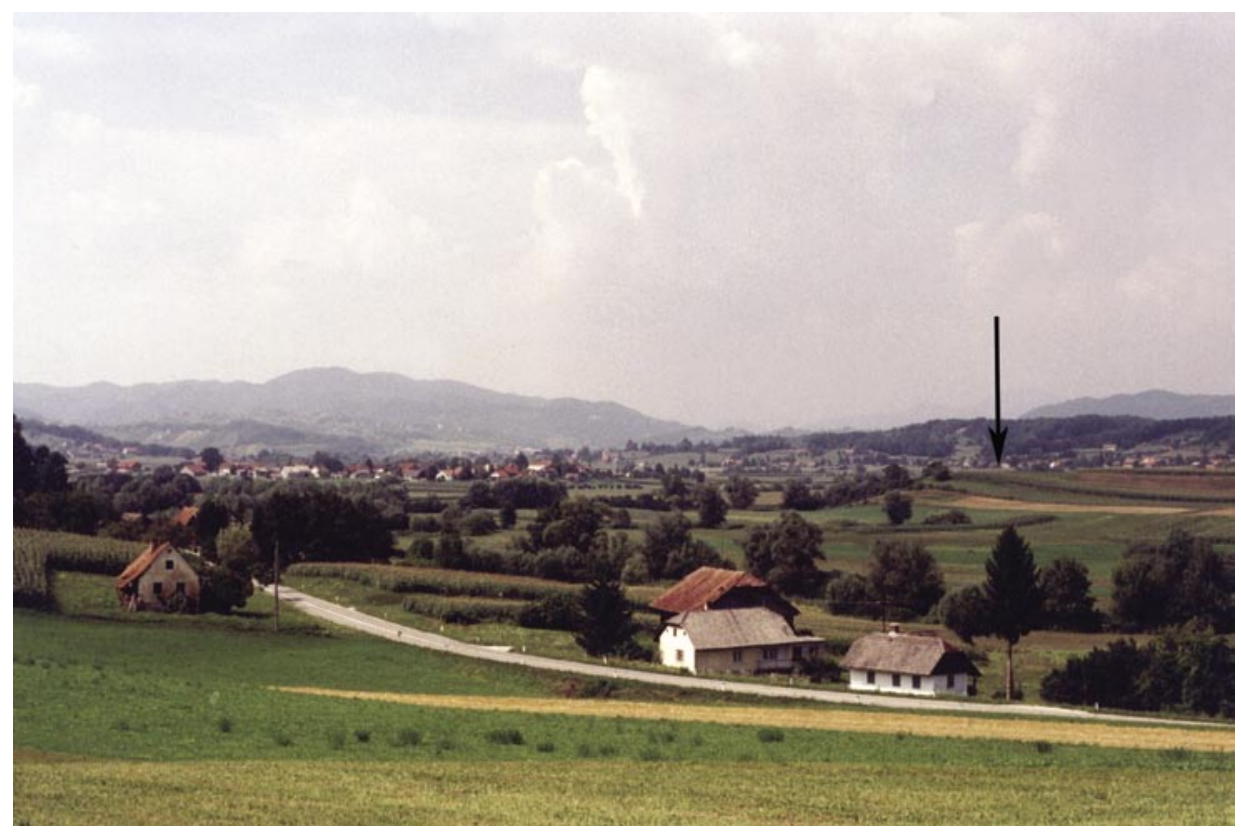

Fot. 4. Pogled u pravcu SSZ na dolinu Sutle s lijepo izraženim erozijskim fragmentom terase rijeke Sutle, (autori: Zdravka Žiger Žgela, Andrija Bognar)

Phot. 4. A view (towards the NNW) of the Sutla valley with a nicely accentuated erosion fragment of the river Sutla terrace, (authors: Zdravka Žiger Žgela, Andrija Bognar)

dvostruke Z ocrte uzdužnog profila vodotoka i njegove doline. Osim toga, uočeni su različiti pomaci krila (jugozapadnog kod Desinićke gore, a sjeveroistočnog kod Rudnice) što je izraz tzv. simple sheare deformacije. Prisutna je rotacija masa oko njihove vertikalne osi. Njezinim istezanjem nastaje ridle-low sustav rasjeda i kao posljedica toga nastanak zjapećih pukotina (proširenje sutjeske!) u zoni rasjeda. Utjecalo je to i na izmjene mehanizama voda vodotoka čime se može objasniti i nedostatak riječnih terasa u okviru sutjeske (Prelogović i dr. 1997), (Foto. 3 i 4).

Proširenje doline Sutle od Poljane Sutlanske do Zagorskih sela obilježeno je s dva manja kotlinska proširenja, prvo u području Miljana-Imeno, i drugo Zagorska Sela - Sedlarjevo. U tim proširenjima energija reljefa je pretežito $30-100 \mathrm{~m} / \mathrm{km}^{2}$, a uz samu rijeku Sutlu iznosi $5-30 \mathrm{~m} / \mathrm{km}^{2}$. Prostor uz samu Sutlu obilježavaju nagibi od $0-2^{\circ}$, a ostale povišene terene nagibi od 5-12 ${ }^{\circ}$. U području između Plavića i Prelaskog došlo je do oblikovanja suženja na 800-900 m na dužini oko $0,5 \mathrm{~km}$ utjecajem kompresijskih pokreta uz rasjede karakteriziranim desnim pomacima posebno uz rasjede pravca pružanja JZ-SI koji ograničavaju tektonske blokove Tisovca, Kunšperka i Cesargradske gore. Rijeka Sutla u ovom sektoru izrazito meandrira s tim da joj je korito relativno duboko usječeno pa se može reći da otječe erozijsko-akumulacijskim podtipom mehanizama voda srednjeg toka. 


\section{MORFOGENETSKI ELEMENTI RELJEFA DOLINE}

Svojstva mehanizama voda rijeke Sutle i njene izmjene tijekom pleistocena i holocena koje se odvijaju pod utjecajem rasjeda koji poprečno sijeku uzdužni profil rijeke, zatim aktivnost padinskih procesa uz utjecaj mlađe tektonike (rasjedne!), litologija, te antropogena aktivnost, imali su odlučujuću ulogu u oblikovanju dolinskih strana, poloja, terasa i korita vodotoka.

\section{Korito}

Morfološki razvoj korita rijeke Sutle prvenstveno je ovisan o faktorima erozije, a to su fluviorapcija ili tzv. pokretačka snaga voda rijeka, korozija vode, atricija i korazija. Krećući se laminarno i turbulentno, vode vodotoka mehanički destruiraju strane i dno korita, noseći nanos nizvodno. U oblikovanju svog uzdužnog profila Sutla je bitno utjecana tektonskim pokretima, sastavom, proticajem i nanosom. Ima izrazito neusuglašeni uzdužni profil obilježen nizom pregiba. Redovno je uz rasjede, gdje je povećan pad rijeke, snažno njeno usijecanje. Utvrđeno je nekoliko rasjeda koji poprečno sijeku njen uzdužni profil rijeke što je izraženo u izmjenama osobina mehanizama voda. Uz rasjede, nagibi korita su redovito povećani, obilježeni prevladavajućom erozijom u okviru mehanizama voda gornjeg toka. Na ostalim dijelovima Sutla otječe mehanizmom srednjeg toka, meandrirajući (tab. 1, 2 i 3).

\section{Regulacije.}

Početkom sedamdesetih prošlog stoljeća počela je izgradnja Sutlanskog jezera na dijelu toka Sutle od Rogateca do Atomskih toplica u podnožju Desinićke gore. Funkcija vodne akumulacije bila je opskrba pitkom vodom naselja bivših općina Šmarje, Klanjec i Krapina, zadržavanje visokih vode osiguranje od poplava nizvodnog dijela toka rijeke Sutle, zatim natapanje obradivih površina, turizam i ribnjičarstvo. Akumulacija je bila duga $7 \mathrm{~km}$, široka od 100 do $150 \mathrm{~m}$. zauzimala je 195,5 ha zemljišta, a zapremnina joj je iznosila 20 milijuna $\mathrm{m}^{3}$. Slijevna površina dotoka voda do pregrade bila je $109 \mathrm{~km}^{2}$. Srednja godišnja količina Sutle bila bi 58 milijuna $\mathrm{m}^{3}$ (Marinček 2000). S punjenjem akumulacije počelo se 1980. Voda je zbog premalog dotoka nakon nekoliko godina postala tako onečišćena da su je 1986. morali ispustiti iz jezera. To je i razumljivo obzirom na činjenicu da su je u velikoj mjeri onečistile otpadne vode iz industrijskih pogona u Rogatecu i Rogaškoj Slatini, te domaćinstva. Onečišćenja su uzrokovala pomor riba i ostalog živog svijeta u jezeru, a ispuštena voda je uništila riblji svijet nizvodno od Sutlanskog jezera.

Tab. 1. Karakteristični vodostaji rijeke Sutle na vodomjeru Miljana i Zelenjak (u cm)

Tab. 1. Waterstage values of the river Sutla on the water gauge station in Miljana and in Zelenjak (in cm)

\begin{tabular}{|c|c|c|c|c|c|c|}
\hline Vodomjer & $\begin{array}{c}\text { Kota «0» } \\
\text { vode }(\mathrm{mnv})\end{array}$ & $\begin{array}{c}\text { Najniži } \\
\text { sred. vodo- } \\
\text { staj }(\mathrm{cm})\end{array}$ & $\begin{array}{c}\text { Srednja } \\
\text { vrijednost } \\
\text { vodostaja } \\
(\mathrm{cm})\end{array}$ & $\begin{array}{c}\text { Najviši sred. } \\
\text { vodostaj } \\
(\mathrm{cm})\end{array}$ & $\begin{array}{c}\text { Najniži } \\
\text { zabilježeni } \\
\text { vodostaj } \\
(\mathrm{cm})\end{array}$ & $\begin{array}{c}\text { Najviši } \\
\text { zabilježeni } \\
\text { vodostaj } \\
(\mathrm{cm})\end{array}$ \\
\hline Miljana & 184,96 & 19 & 64 & 372 & $\begin{array}{c}45 \\
22.06 .1984 .\end{array}$ & $\begin{array}{c}38.10 .1975 . \\
180.19\end{array}$ \\
\hline Zelenjak & 166,8 & 48 & 81 & 314 & $\begin{array}{c}56 \\
25.08 .1967 .\end{array}$ & $\begin{array}{c}448 \\
21.10 .1974 .\end{array}$ \\
\hline
\end{tabular}

Izvor: Hidrološki godišnjak Jugoslavije od 1958.-1986.,Savezni Hidrometerološki zavod, Beograd 
Hrvatski geografski glasnik 69/1 (2007.)

Tab. 2. Podaci o količinama nanosa u rijeci Sutli i u okviru poriječja rijeke Sutle Tab. 2. Values of the fluvial wash in the Sutla river basin.

\begin{tabular}{|c|c|c|c|c|c|c|}
\hline 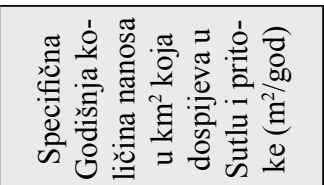 & $\mathcal{I}$ & 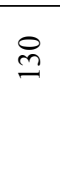 & 8 & $\stackrel{\sim}{\Omega}$ & $\infty$ & $\infty$ \\
\hline 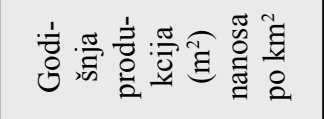 & กี & $\stackrel{\sim}{\sim}$ & : & तิ & $\stackrel{\text { సे }}{ }$ & $\stackrel{\text { ন }}{ }$ \\
\hline 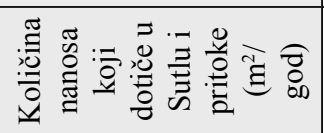 & ষ̊̊ి & $\underset{\infty}{\infty}$ & $\stackrel{\circ}{ }$ & $\begin{array}{l}8 \\
0 \\
0\end{array}$ & i & $\stackrel{8}{0}$ \\
\hline 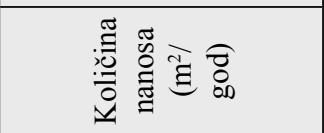 & $\frac{0}{n}$ & 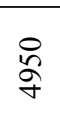 & $\underset{\sim}{\stackrel{+}{d}}$ & 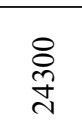 & ָి & 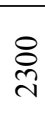 \\
\hline 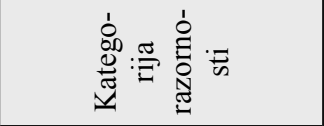 & & $\ddot{z}$ & $\dot{z}$ & $>$ & $>$ & $>$ \\
\hline 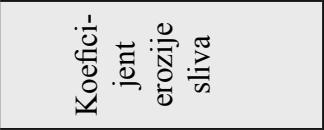 & & $\begin{array}{l}\tilde{N} \\
\text { on }\end{array}$ & $\begin{array}{l}\tilde{z} \\
0\end{array}$ & $\stackrel{\Xi}{0}$ & $\frac{\partial}{0}$ & $\frac{2}{0}$ \\
\hline 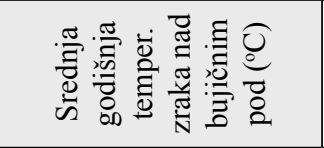 & $\stackrel{0}{=}$ & $\stackrel{0}{0}$ & 0 & $\infty_{\infty}$ & $\stackrel{0}{0}$ & : \\
\hline 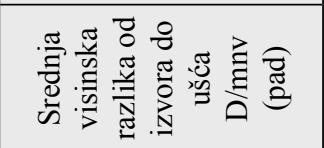 & & $\frac{N}{0}$ & $\frac{8}{0}$ & $\begin{array}{l}\text { 苞 } \\
\text { ô }\end{array}$ & $\begin{array}{l}\vec{\alpha} \\
\stackrel{0}{0}\end{array}$ & ڤે \\
\hline 言. & & $\stackrel{0}{0}$ & $\stackrel{n}{=}$ & $\frac{1}{6}$ & $\stackrel{N}{=}$ & $\stackrel{n}{=}$ \\
\hline 湑 & $\ddot{a}$ & $\begin{array}{l}0 \\
\stackrel{+}{*}\end{array}$ & $\begin{array}{l}0 \\
+\end{array}$ & $\hat{\stackrel{\infty}{\sim}}$ & $\begin{array}{l}n \\
\because\end{array}$ & $\stackrel{n}{=}$ \\
\hline 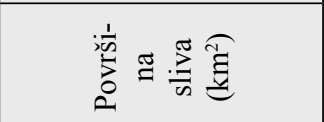 & $\underset{\substack{0 \\
\infty \\
i n}}{i}$ & $\stackrel{\infty}{\stackrel{n}{n}}$ & $\infty_{0}^{\infty}$ & 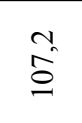 & $\begin{array}{l}0 \\
\stackrel{+}{*}\end{array}$ & $\mathrm{C}_{\infty}$ \\
\hline 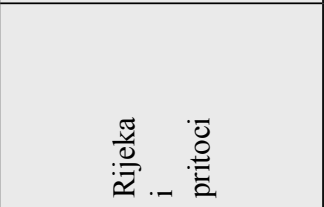 & $\begin{array}{l}\overleftrightarrow{3} \\
\stackrel{S}{S}\end{array}$ & 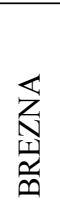 & 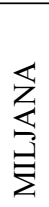 & 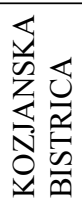 & 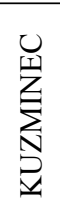 & 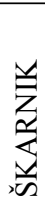 \\
\hline
\end{tabular}

Izvor: Erozija i nanos sliva rijeke Sutle (1969.), I separat, Zagreb 
Tab.3. Vrijednosti nagiba pada uzdužnog profila rijeke Sutle od izvora do ušća

Tab.3. Values of longitudinal profile inclinacion of the river Sutla from the well to the mouth in the river Sava.

\begin{tabular}{|l|c|c|c|c|c|}
\hline Mjesto & $\begin{array}{c}\text { Udaljenost od } \\
\text { ušća }(\mathrm{km})\end{array}$ & $\begin{array}{c}\text { Udaljenost od } \\
\text { izvora }(\mathrm{km})\end{array}$ & $\begin{array}{c}\text { Kota } \ll 0 » \\
\text { točke }\end{array}$ & $\begin{array}{c}\text { Ukupan } \\
\text { pad }(\mathrm{cm})\end{array}$ & $\begin{array}{c}\text { Pad } \\
(\mathrm{cm} / \mathrm{km})\end{array}$ \\
\hline IZVOR & 95,486 & 0 & 625,0 & - & - \\
\hline TRLIČNO & 88,486 & 7,0 & 258,0 & 36700 & 5242,85 \\
\hline DOBOVEC & 83,486 & 12,0 & 235,0 & 2300 & 460,0 \\
\hline ROGATEC & 77,486 & 18,0 & 220,0 & 1500 & 250,0 \\
\hline RAJNKOVEC & 71,486 & 24,0 & 211,0 & 900 & 150,0 \\
\hline ROGAŠKA & 71,0 & 24,486 & 210,0 & 100 & 205,76 \\
\hline SLATINA & 68,486 & 27,0 & 206,0 & 400 & 159,10 \\
\hline PRIŠLIN & 60,486 & 35,0 & 196,0 & 1000 & 125,0 \\
\hline VONARJE & 56,486 & 39,0 & 193,2 & 280 & 70,0 \\
\hline PODČETRTEK & 51,486 & 44,0 & 184,96 & 824 & 164,80 \\
\hline MILJANA & 45,486 & 50,0 & 180,0 & 496 & 82,66 \\
\hline SEDLARJEVO & 36,0 & 59,486 & 177,8 & 222 & 23,19 \\
\hline POLJE PRI BISTRICI & 30,486 & 65,0 & 166,8 & 1100 & 199,49 \\
\hline ZELENJAK & 28,486 & 67,0 & 161,0 & 580 & 290,0 \\
\hline KLANJEC & 24,486 & 71,0 & 158,0 & 300 & 75,0 \\
\hline GORNJA VAS & 16,486 & 79,0 & 150,0 & 800 & 100,0 \\
\hline GREGOVCE & 11,486 & 84,0 & 143,0 & 700 & 140,0 \\
\hline SLOGONSKO & 8,486 & 87,0 & 139,21 & 379 & 126,3 \\
\hline RAKOVEC & 3,486 & 92,0 & 136,0 & 329 & 64,2 \\
\hline RIGONCE & 0 & 95,486 & 132,5 & 350 & 100,4 \\
\hline UŠĆE U SAVU & 95,486 & 95,486 & & 48756 & 510,6 \\
\hline UKUPNO & & & & & \\
\hline
\end{tabular}

Tablica je konstruirana na temelju podataka iz studije: Marinček, Matija: «Stacionaža reke Sotle» VPG, 2000.

\section{Poloj}

Poloj rijeke Sutle je razvijen duž čitavog njegovog uzdužnog profila. Značajke mehanizma vode te utjecaj tektonskih pokreta u znatnoj mjeri su utjecali na granulometrijski sastav naplavine Sutle i na njegovu širinu. Poloj je širi u kotlinskim proširenjima i uži je u sutjeskama gdje je tijekom oblikovanja doline uglavnom prevladavao mehanizam gornjeg toka, dakle usijecanje. U proširenim dijelovima doline prevladavala je akumulacija i to tamo gdje vodotok otječe mehanizmom voda srednjeg toka. U okviru poloja rijeke Sutle, u čijem je sastavu pretežu akumulacije pijeska i šljunka, a manje glina i ilovača, razlikuje se uglavnom viši nivo poloja. Posljedica je to prevladavajuće erozijsko-akumulacijske podvarijante mehanizama voda srednjeg toka zbog konstantne prisutnosti pozitivnih 
tektonskih pokreta. Geomorfološka analiza govori u prilog činjenice da se čitavo poriječje Sutle nalazi u stalnom relativnom izdizanju s tim da je u kotlinskim proširenjima ono nešto slabije izraženo pa se u odnosu na okolna uzvišenja tu može govoriti o relativnom spuštanju. Sve to utječe da se rijeka meandrirajuće usijeca pa do plavljenja dolazi samo za veoma visokih voda. Poplave su stoga u dolini rijeke Sutle rijetke i uglavnom dugotrajnije u onim dijelovima gdje je izrazitije relativno spuštanje. Najbolji primjer toga je dio doline Sutle u predgorskoj potolini Desinićke gore, gdje je zbog upravo čestih plavljenja izgrađena akumulacija Vonarjevo (Sutlansko jezero). Pojava poplava u poloju često je vezana za bujične pritoke Sutle.

\section{Terase.}

Od izvorišta pa do Klanjca rijeka Sutla je oblikovala niz erozijskih podova i dva terasna fragmenta akumulacijskog tipa. Erozijski podovi uočeni su u okviru više sektora od Hromca pa do Poljane Sutlanske. Javljaju se na obje dolinske strane, ali nisu kontinuirani, te imaju različitu visinu iznad današnje naplavne ravnice rijeke Sutle (od 20-100 m relativne visine). Erozijski pod je iste relativne starosti, ali je mlađim tektonskim pokretima poremećen i doveden u različite hipsometrijske nivoe. Erozijski pod je ishodišni, primarni nivo u koji se vodotok usjekao u početnom stadiju svoje evolucije (vjerojatno tijekom pleistocena). U istraživanom dijelu doline rijeke Sutle osim kod Sedlarjeva, nije sačuvana ni jedna akumulacijska terasa. Uzrok tome leži u činjenici da ukoliko je u pojedinim fazama bila izražena akumulacija, rijeka je iste u fazama intenzivnije bočne erozije uglavnom erodirala. Terasa kod Sedlarjeva koja je povišena nad današnjom naplavnom ravnice Sutle cca 7-10 m predstavlja de facto erozijski fragment nekad postojeće akumulacije (starijeg poloja) koja je nastala u tektonski mirnijim fazama, kada je prevladavalo taloženje. Erozijsko-akumulacijski fragment kod Rogateca nije primarna riječna akumulacija Sutle, već predstavlja ostatak Sutlom erodirane plavine potoka Draganje - pseudoterasu Sutle.

\section{Dolinske strane}

Poriječje Sutle je u velikoj mjeri obraslo šumskom vegetacijom, a dijelom se koristi kao poljodjelsko-vinogradarske površine. Izrazita reljefna energija i povećani nagibi pobrđa oblikovanog u litološki gledano «mekšim» klastitima potiču spiranje i jaruženje, a česta je pojava klizišta. Većina derazijskih dolina na pobrđima i na dolinskim stranama Sutle disecirana je brojnim jarugama i vododerinama. Utjecajem spiranja i kliženja jaruge se šire pa se oblikuju suhe derazijske doline. Jaruge se uglavnom vežu za pješčenjake i pijeske, dok su klizišta vezana za terene u čijem sastavu sudjeluju glinovite čestice. Brojne jaruge su usječene na dolinskim stranama Sutle uz gorske hrptove Rudnice i Desinićke gore, te u pobrđu Maceljske i Horvatske gore. Obzirom na velike nagibe (najčešće od 25-30) jaruge su i danas u funkciji. Završavaju bujičnim, proluvijalnim plavinama u podnožju brdskih blokova. (S1. 5) 


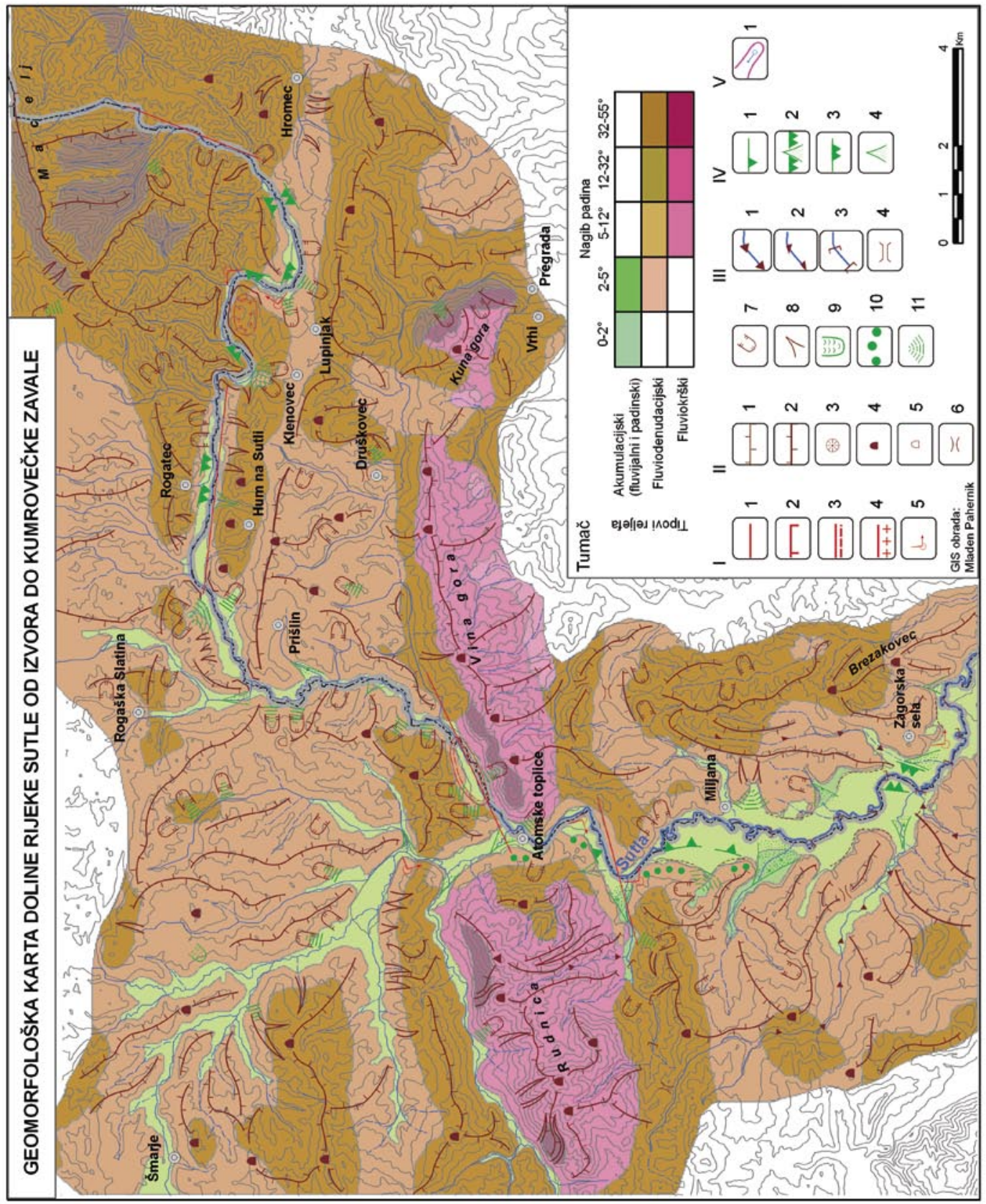

S1.5. Geomorfološka karta doline rijeke Sutle od izvora do Kumrovečke zavale

Fig.5. Geomorphological map of the river Sutla valley from the well to the plain of Kumrovec 


\section{ZAKLJUČAK}

Geomorfološka analiza doline rijeke Sutle dokazala je kompozitni karakter doline što je rezultat djelovanja mlađih tektonskih pokreta ifluviodenudacijskih procesa. Promjenom intenziteta tih procesa mijenjao se i mehanizam voda rijeke Sutle. U orografskom, morfogenetskom i morfostrukturnom smislu mogu se izdvojiti kotlinska proširenja i suženja - sutjeske na uzdužnom profilu doline što govori u prilog činjenici da se čitavo poriječje Sutle nalazi u stalnom relativnom izdizanju. U nastanku sutjeske kod Podčetrtka postoje dva moguća objašnjenja. Prvo je tumačeno epigenetskim tipom morfogeneze, a drugo se veže za izmjenu djelovanja tektonskog stresa i rotiranja geoloških struktura Desinićke gore i Rudnice. U formiranju današnjih osobina dolinskih strana, poloja, korita vodotoka i erozijskih podova odlučujuću ulogu su imali svojstva mehanizama voda i njihove promjene tijekom pleistocena i holocena i padinski procesi.

\section{NOTES}

1. Misli se na pobrđe oblikovano u tercijernim naslagam omeđeno Kumrovečkom zavalom, gorskim nizom Tisovac, Orlika, Kunšperk, na JZ gorskim uzvišenjem Bredića, a na SZ gorskim hrptom Rudnice. 